\title{
Purification and Characterization of Cellulase from Termite Ametermes eveuncifer (Silverstri) Soldiers
}

\author{
B. S. Fagbohunka ${ }^{1}$, R. E. Okonji ${ }^{2} \&$ Ayinla Zainab Adenike ${ }^{2}$ \\ ${ }^{1}$ Department of Biochemistry, Faculty of Basic Medical Science, Olabisi Onabanjo University, Nigeria \\ ${ }^{2}$ Department of Biochemistry and Molecular Biology, Faculty of Science, Obafemi Awolowo University, Nigeria \\ Correspondence: Ayinla Z.A., Department of Biochemistry and Molecular Biology, Obafemi Awolowo \\ University, Nigeria. E-mail: mailnike2001@yahoo.co.uk; zsalimanu@oauife.edu.ng
}

Received: November 22, 2016

Accepted: December 6, 2016 Online Published: December 21, 2016

doi:10.5539/ijb.v9n1p1

URL: http://dx.doi.org/10.5539/ijb.v9n1p1

\begin{abstract}
Cellulase enzyme was purified and characterized from termite soldiers (Ametermes eveuncifer) using 70\% ammonium sulphate precipitation, ion exchange chromatography and affinity chromatography. The enzyme isolated had a specific activity of $5.04 \mathrm{U} / \mathrm{mg}$ with a percentage yield of $11.7 \%$. The enzyme showed maximum activity at $50^{\circ} \mathrm{C}$ and $\mathrm{pH} 8$. The enzyme was not inhibited by $\mathrm{Ba}^{2+}$ at a concentration of $1 \mathrm{mM}$ and $\mathrm{Pb}^{2+}$ at $10 \mathrm{mM}$ concentration but was inhibited by other metal ions at $1 \mathrm{mM}$ and $10 \mathrm{mM}$ concentrations of their salts $(\mathrm{NaCl}, \mathrm{KCl}$, $\mathrm{MnCl}_{2}$, and $\mathrm{NiCl}_{2}$,
\end{abstract}

Keywords: Cellulase, termite soldier, Ametermes eveuncifer, purification

\section{Introduction}

Termites' ability to digest wood and cause significant structural damage to buildings is what majorly distinguishes them from other insect pests. This ability to digest wood is due mainly to the complex array of carbohydrolases which confer on them the ability to digest cellulose and hemicelluloses such as xylan (Whistler \& Chen, 1991). Termites are among the most significant wood-feeders on earth. To efficiently digest cellulose for survival, Ametermes eveuncifer (Silverstri) require cellulase for the enzymatic hydrolysis of polysaccharide to glucose (Fagbohunka et al., 2015).

The major nutritional component for wood-feeding termites is cellulose, which is plant's main structural constituent. Apart from being structural pests, termites have a huge impact on terrestrial ecological processes, as they are part of the main terrestrial cellulose recyclers (Inoue et al., 1997). Cellulase activity in the midgut of these insects is very high (Hogan et al., 1988), and studies have shown that they rely solely on their own cellulases (Slaytor, 1992; Slaytor, 2000) rather than the cellulases of symbiotic bacteria present in their lower intestine (Brune \& Stingl, 2005).

Based on their mode of action, three varieties of cellulase exist which any highly cellulolytic organism must possess (Breznak \& Brune 1994). Exoglucanases (EC 3.2.1.91) are the first class of cellulases. The second class of cellulases consists of the endoglucanases (EC 3.2.1.4) while the third class is the beta-glucosidases (EC 3.2.1.21). Exoglucanases bind to the end of a cellulose chain and breaks it down as it moves along the chain length. Most exoglucanases reduce cellulose to cellobiose (a beta-glucose disaccharide) and are said to be cellobiohydrolases. Endoglucanases, on the other hand, bind anywhere along the cellulose chain and break it up randomly, thus reducing it to cellodextrins (beta-glucose oligosaccharides). Beta-glucosidases break cellodextrins down into glucose. They are the last enzyme in the process of generating glucose from cellulose (Mishra, 1991).

In recent times, there have been studies on the diverse cellulase activity in each gut segments of termites (Willis et al. 2010). Findings by Tokuda et al. $(2004,2005)$ established that the endogenous cellulase genes were expressed in the salivary glands of lower termites while being expressed in the midgut of higher termites. Mo et al. (2004) and $\mathrm{Lu}$ et al. (2010) also independently compared the differences in total cellulase activity among lower termites, while Fujita et al. (2008) reported the differences in cellulase expression between soldier and worker termites of Hodotermopsis sjostedti and Nasutitermes Takasagoensis.

The use of cellulase in various industrial processes is indispensable. It is used in plants and agricultural waste processing (Mswaka \& Magan, 1998; Lu et al., 2004), biofuels (Vaithanomsat et al., 2009), triphase 
biomethanation (Chakraborty et al., 2000), chiral separation and ligand binding studies (Nutt et al., 1998). An in-depth study of the enzymes involved in the degradation of cellulose and other polysaccharides in termites will play a key role towards discovering novel approaches in termite control, removal of cellulosic waste, improved knowledge of polysaccharide degradation which might drive the discovery of novel industrial enzymes as well as industrial methods in alternative fuel generation from cellulosic materials. This study reports the purification and physicochemical properties of cellulase from Ametermes eveuncifer soldiers.

\section{Materials and Methods}

\subsection{Reagents and Apparatus}

Sodium chloride, potassium chloride, lead chloride, barium chloride, manganese chloride, nickel chloride and ammonium sulphate, were purchased from BDH Chemical Limited, Poole England. EDTA and Carboxymethyl-cellulose were purchased from Sigma Chemical Company, St. Louis, USA. All other reagents were of high analytical grade and used without further purification. The agro-industrial wastes (banana peel, rice husk, orange mesocarp, pineapple peel, maize cob) used were obtained locally, ground to powder using mechanical grinder, sieved and dissolved in the assay buffer. These wastes were used without prior pre-treatment. Termite soldiers (A. eveuncifer) were collected from South-Western part of Nigeria.

Apparatus used include, mortar and pestle, weighing balance (Mettler PN1210), pH meter (PHS-25), Centrifuge (Helmreasinn 80-2) and UV/VIS Spectrophotometer (Bosch 752N).

\subsection{Enzyme Extraction and Purification}

Termite soldiers were washed and rinsed with distilled water. The termites were gently homogenized in $10 \mathrm{mM}$ sodium acetate buffer, $\mathrm{pH}$ 5.0, containing $1 \mathrm{mM}$ EDTA. The mixture collected was centrifuged at 15,000 rpm for 15 minutes at room temperature. The supernatant, which served as the crude enzyme, was collected and stored in a refrigerator. The supernatant was salted out by bringing the crude extract to $70 \%(\mathrm{w} / \mathrm{v})$ saturation with Ammonium sulphate.

\subsection{Cellulase Assay and Protein Concentration Determination}

Bradford method (1976) was used to measure the protein concentration of the enzyme using bovine serum albumin (BSA) as standard. Cellulase activity was assayed according to the method of Zhang et al. (2006), with slight modification, using $1 \%$ Carboxymethyl-cellulose (CMC) as the substrate. CMC was dissolved in $10 \mathrm{mM}$ citrate buffer ( $\mathrm{pH}$ 5.0). The reaction mixture, containing $50 \mu \mathrm{L}$ of the enzyme and $450 \mu \mathrm{L}$ of CMC, was incubated at $50^{\circ} \mathrm{C}$ for $30 \mathrm{~min}$. The reaction was terminated by adding $2 \mathrm{ml}$ of 3,5-Dinitrosalicylic acid (DNSA) reagent. The mixture was then boiled for $30 \mathrm{~min}$ and optical density reading was taken at $540 \mathrm{~nm}$. One unit of cellulase activity was expressed as the amount of enzyme that released $1 \mu \mathrm{mol}$ of reducing sugars (glucose equivalent) in 1 min under the above conditions. A standard calibration curve of glucose was constructed and used for the estimation.

\subsection{Ion Exchange Chromatography}

A CM-Sephadex C-25 cation exchanger was equilibrated with $10 \mathrm{mM}$ sodium citrate buffer $\mathrm{pH}$ 4.8. The precipitated enzyme was dialysed against several changes of buffer before being layered on the column $(1.5 \times 25$ $\mathrm{cm}$ ). The column was then washed with the same buffer (citrate buffer, $\mathrm{pH} 4.8$ ) to remove the unbound protein, followed by elution with $0.1 \mathrm{M} \mathrm{KC1}$ in $50 \mathrm{mM}$ sodium citrate buffer, $\mathrm{pH} 4.8$. Fractions $(3 \mathrm{ml})$ were collected from the column at a rate of $60 \mathrm{ml} / \mathrm{h}$. The fractions were assayed for cellulase activity using the DNSA method and active fractions were pooled and immediately dialysed against $50 \%$ glycerol in the elution buffer to store the enzyme. Protein was determined by Bradford assay by measuring O.D at $595 \mathrm{~nm}$.

\subsection{Affinity Chromatography}

Agarose Blue resin was packed into a $1.5 \times 10 \mathrm{~cm}$ column and equilibrated with $10 \mathrm{mM}$ citrate buffer (pH 4.8). Then the sample was applied on the column. The column was then washed with the buffer to remove unbound protein, followed by elution with $1 \mathrm{M} \mathrm{KC1}$ in the same buffer. Fractions of $2 \mathrm{ml}$ were collected from the column at a rate of $16 \mathrm{ml} / \mathrm{h}$. Protein was monitored by Bradford assay at $595 \mathrm{~nm}$ and the fractions were assayed for cellulase activity following the assay method described above. The active fractions were pooled and immediately dialysed against $50 \%$ glycerol in citrate buffer ( $\mathrm{pH} 4.8$ ) to store the enzyme.

\subsection{Effect of Temperature}

Cellulase activity was assayed at temperatures between $30{ }^{\circ} \mathrm{C}$ and $100{ }^{\circ} \mathrm{C}$ at $\mathrm{pH} 5.0$ to investigate the effect of temperature on the activity of the enzyme and to determine the optimum temperature of the enzyme. The assay mixture was first incubated at the respective temperature for $10 \mathrm{~min}$ before initiating reaction by the addition of an 
aliquot of the enzyme which had been equilibrated at the same temperature. The cellulase activity was assayed routinely as previously described in section 2.3 .

\subsection{Effect of $p H$}

The effect of $\mathrm{pH}$ on the enzyme activity was performed by assaying for enzyme activity at a $\mathrm{pH}$ range of 3 to 11 at $37^{\circ} \mathrm{C}$ using varying buffers of different $\mathrm{pH}$ : $50 \mathrm{mM}$ of citrate $(\mathrm{pH} 3-5)$; phosphate $(6-8)$ and borate $(\mathrm{pH} 9-11)$. The cellulase activity was assayed as previously described in section 2.3 .

\subsection{Effect of Salts}

The effect of various metal ions on the activity of termite cellulase was studied using the following chloride salts: $\mathrm{NaCl}, \mathrm{KCl}, \mathrm{BaCl}_{2}, \mathrm{MnCl}_{2}, \mathrm{PbCl}_{2}$ and $\mathrm{NiCl}_{2}$ at final concentrations of $1.0 \mathrm{mM}$ and $10.0 \mathrm{mM}$ in the enzyme assay.

\subsection{Substrate Specificity}

The substrate specificity of the enzyme was determined by using various agroindustrial wastes as carbon sources such as banana peel, rice husk, orange mesocarp, pineapple peel and maize cob in a typical cellulase assay mixture and the activity expressed as percentage residual activity of the enzyme.

\subsection{Inhibition Studies}

The inhibition study was carried out using various chelating agents including EDTA, urea and mercaptoethanol at final concentrations of $1.0 \mathrm{mM}$ and $10.0 \mathrm{mM}$ and the percentage residual activity determined.

\section{Results}

\subsection{Purification}

The summary of the purification procedure for cellulase from the soldier termite is shown in Table 1. The elution profile of the enzyme using ion-exchange chromatography on CM-Sephadex C-25 is shown in Figure 1 while the elution profile of the enzyme using affinity chromatography is shown in Figure 2. The enzyme was purified using $70 \%$ ammonium sulphate precipitation, ion exchange and affinity chromatography.

Table 1. Purification of Cellulase from Termite, Ametermes eveuncifer (Silverstri) Soldiers

\begin{tabular}{cccccc}
\hline PURIFICATION STEPS & $\begin{array}{c}\text { TOTAL } \\
\text { ACTIVITY }(\mathrm{U})\end{array}$ & $\begin{array}{c}\text { TOTAL } \\
\text { PROTEIN } \\
(\mathrm{mg})\end{array}$ & $\begin{array}{c}\text { SPECIFIC } \\
\text { ACTIVITY } \\
(\text { U/mg protein })\end{array}$ & $\begin{array}{c}\text { PURIFICATION } \\
\text { FOLD }\end{array}$ & $\begin{array}{c}\text { YIELD } \\
(\%)\end{array}$ \\
\hline $\begin{array}{c}\text { CRUDE ENZYME } \\
\text { 70\% AMMONIUM SULPHATE }\end{array}$ & 36850.0 & 30708.33 & 1.2 & 1 & 1.2 \\
PRECIPITATION & 37697.54 & 20943.08 & 1.8 & 1.5 & 68.2 \\
ION EXCHANGE & 18682.9 & 7413.85 & 2.52 & 2.1 & 35.4 \\
CHROMATOGRAPHY & 18108.09 & 3592.80 & 5.04 & 4.2 & 11.7 \\
\hline AFFINITY CHROMATOGRAPHY & & & & \\
\hline
\end{tabular}

Each of the steps was carried out as described in the methodology. Cellulase activity was measured following a modified method of Zhang et al. (2006). Protein concentration was determined by the Bradford method (Bradford, 1976). One unit (U) of cellulase activity was expressed as the amount of enzyme that released $1 \mu \mathrm{mol}$ of reducing sugars (glucose equivalent) in 1 min under the assay conditions.

\subsection{Effect of $p H$ and Temperature on Cellulase}

The effect of $\mathrm{pH}$ on the rate of activity of cellulase is shown in Fig. 3. An optimum $\mathrm{pH}$ of 8 was obtained for cellulase. The assay done to investigate the effect of temperature on the activity of cellulase showed the enzyme to have its optimum temperature at $50^{\circ} \mathrm{C}$ as shown in Figure 4.

\subsection{Effect of Salts}

The results of the effect of various salts on the activity of cellulase from the termite soldier (Table 2) showed that $\mathrm{PbCl}_{2}$ at a concentration of $10 \mathrm{mM}$ had no effect whatsoever on enzyme activity while $\mathrm{BaCl}_{2}$ had little effect on enzyme activity at a concentration of $1 \mathrm{mM}$. However, $\mathrm{NaCl}, \mathrm{KCl}, \mathrm{MnCl}_{2}$ and $\mathrm{NiCl}_{2}$ inhibited the activity of the enzyme at concentrations of both 1.0 and $10 \mathrm{mM}$. 


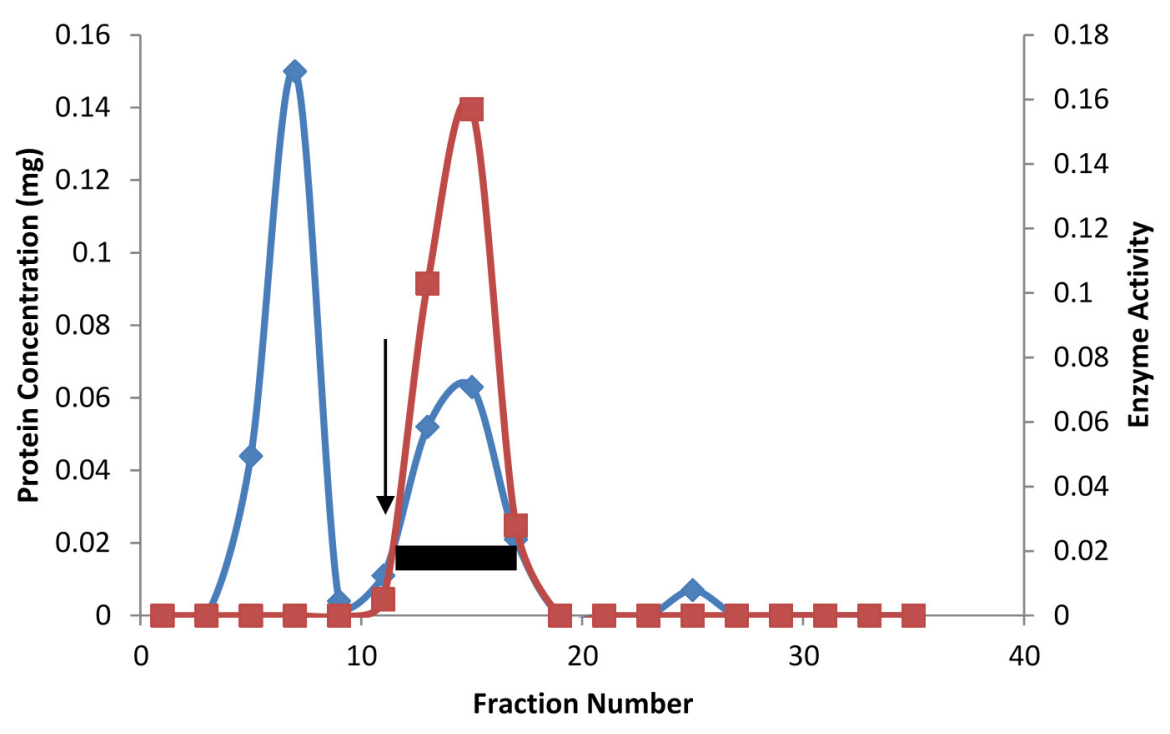

Figure 1. Elution profile of cellulase from termite soldiers using ion-exchange chromatography on a CM-Sephadex C-25 column $(1.5 \times 25 \mathrm{~cm})$. The column was first washed with $10 \mathrm{mM}$ citrate buffer $(\mathrm{pH} 4.8)$ and then eluted with $0.1 \mathrm{M} \mathrm{KCl}$ (the point of elution is indicated by the arrow). Elution was carried out at a flow rate of $60 \mathrm{ml} / \mathrm{h}$ and $3 \mathrm{ml}$ fractions were collected. One active peak was obtained. $\diamond$, Protein concentration $\left(\mathrm{OD}_{595 \mathrm{~mm}}\right) ; \square$, Enzyme Acivity $\left(\mathrm{OD}_{540 \mathrm{~nm}}\right)$; , pooled fraction

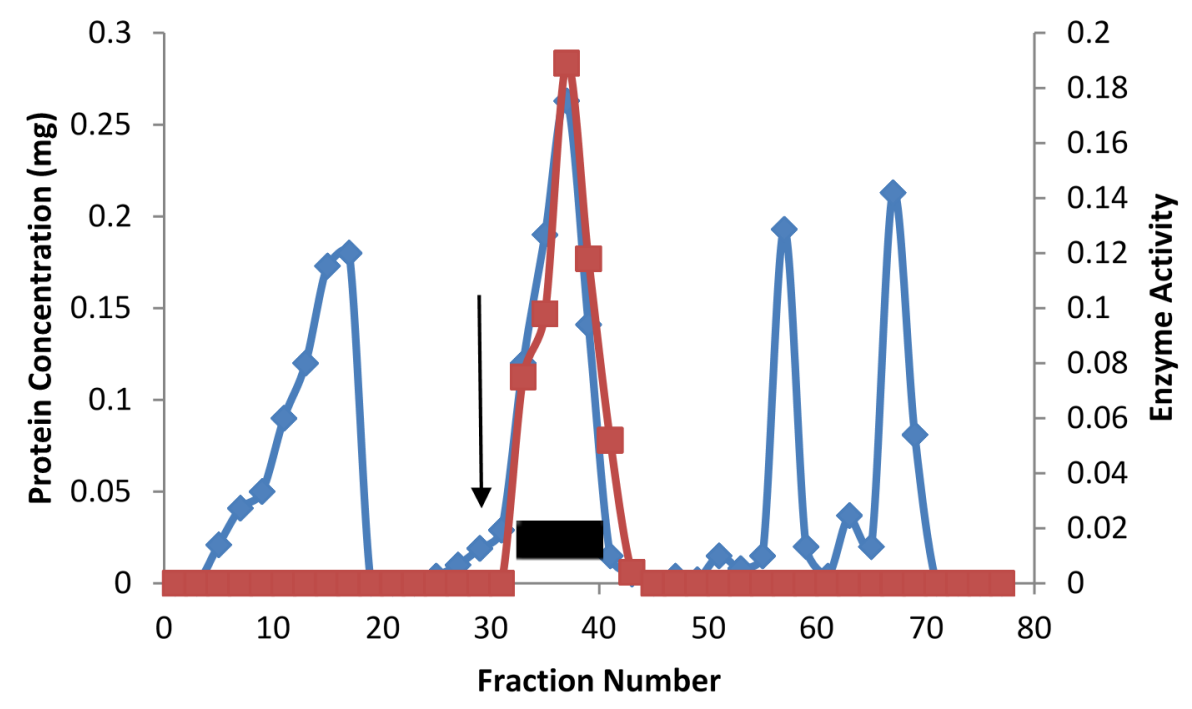

Figure 2. Elution profile of cellulase from termite soldiers using affinity chromatography on an agarose blue resin column $(1.5 \times 10 \mathrm{~cm})$. The column was first washed with $10 \mathrm{mM}$ citrate buffer $(\mathrm{pH} 4.8)$ and then eluted with $1 \mathrm{M} \mathrm{KCl}$ (the point of elution is indicated by the arrow). Elution was carried out at a flow rate of $16 \mathrm{ml} / \mathrm{h}$ and $2 \mathrm{ml}$ fractions were collected. $\diamond$, Protein concentration $\left(\mathrm{OD}_{595 \mathrm{~nm}}\right)$; $\square$, Enzyme Acivity

$$
\left(\mathrm{OD}_{540 \mathrm{~mm}}\right) \text {; }
$$
, pooled fraction 


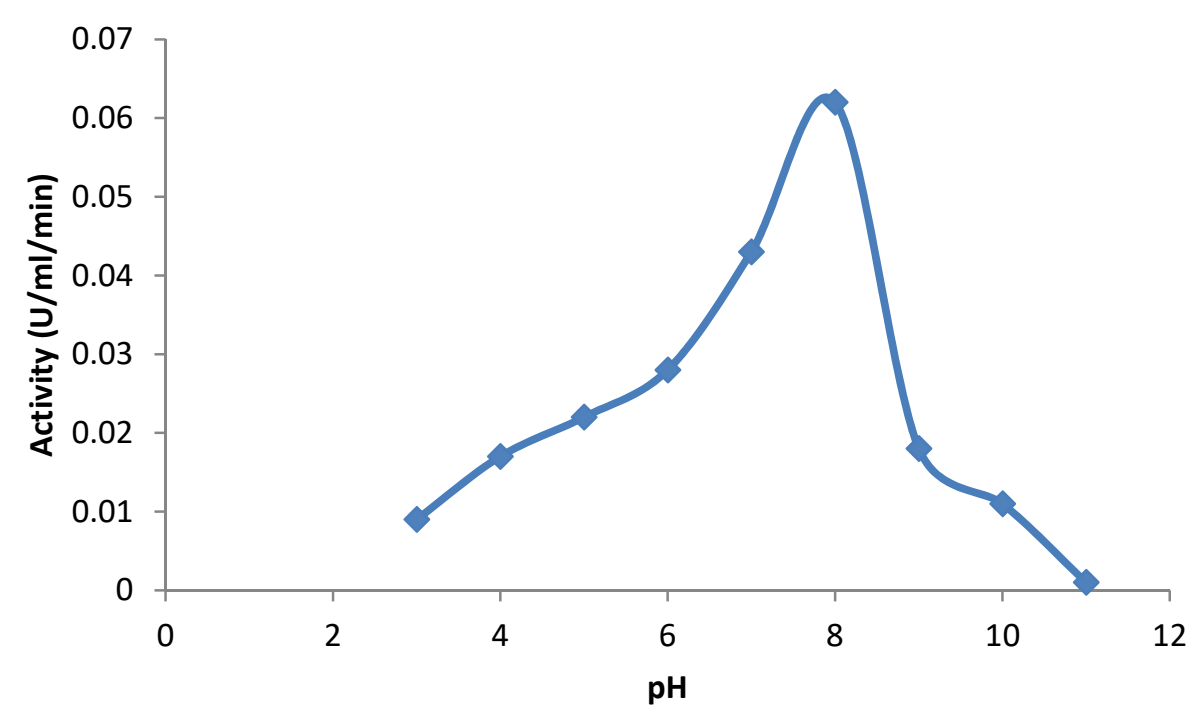

Figure 3. Effect of $\mathrm{pH}$ on Cellulase from Termite, Ametermes eveuncifer (Silverstri) Soldiers

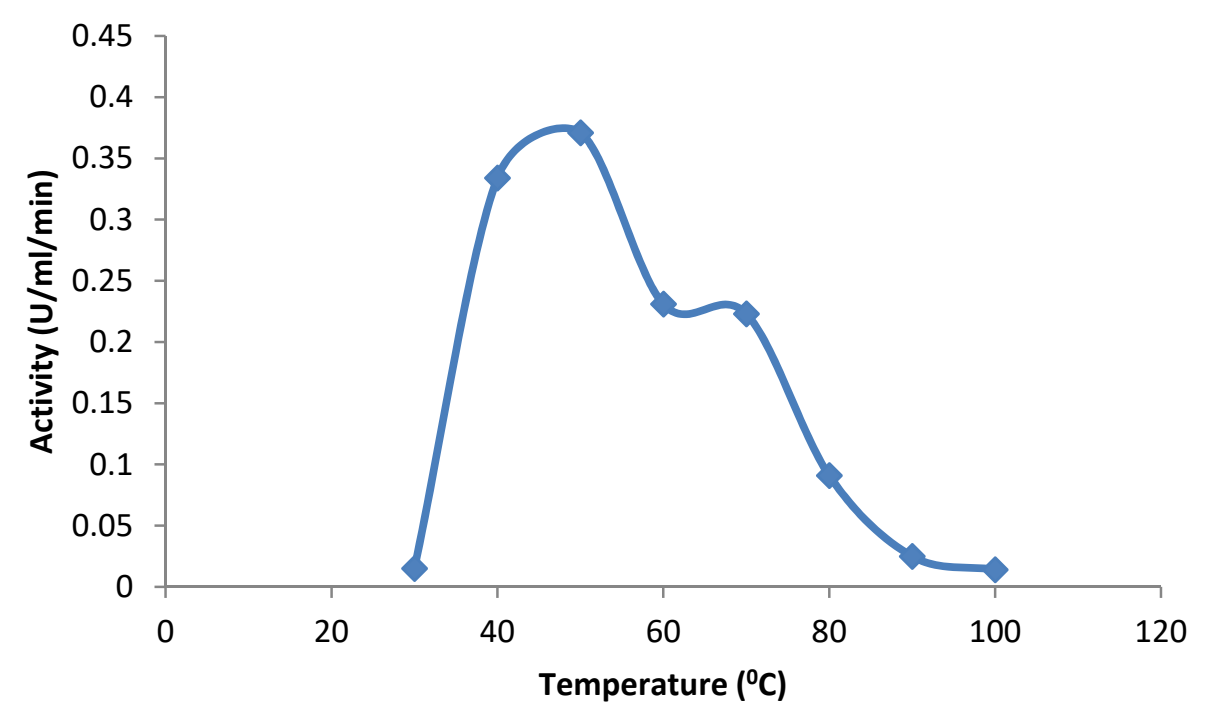

Figure 4. Effect of Temperature on Cellulase from Termite, Ametermes eveuncifer (Silverstri) Soldiers

Table 2. Effects of cations on the activity of cellulase from termite soldiers

\begin{tabular}{ccc}
\hline \multirow{2}{*}{ Salt } & \multicolumn{2}{c}{ \% Residual Activity } \\
\cline { 2 - 3 } & $1.0 \mathrm{mM}$ & $10.0 \mathrm{mM}$ \\
\hline $\mathrm{NaCl}$ & 6.02 & 44.49 \\
$\mathrm{KCl}$ & 56.13 & 40.75 \\
$\mathrm{BaCl}_{2}$ & 79.0 & 20.37 \\
$\mathrm{MnCl}_{2}$ & 23.28 & 0 \\
$\mathrm{PbCl}_{2}$ & 19.13 & 100 \\
$\mathrm{NiCl}_{2}$ & 0 & 14.55 \\
\hline
\end{tabular}

Percentage of residual activity is compared with the activity of the enzyme in the absence of metal ions. 


\subsection{Substrate Specificity}

The purified enzyme showed highest activity against maize cob even though this activity was considerably low. There was no hydrolysis ability against banana and rice husk. A summary of this is shown in Table 3.

Table 3. Substrate specificity of the purified cellulase

\begin{tabular}{ll}
\hline SUBSTRATES & ACTIVITY $(\%)$ \\
\hline BANANA PEEL & 0 \\
RICE HUSK & 0 \\
ORANGE MESOCARP & 0.416 \\
PINEAPPLE PEEL & 0.416 \\
MAIZE COB & 3.326 \\
\hline
\end{tabular}

\subsection{Effect of Inhibitors}

As indicated in Table 4, $10.0 \mathrm{mM} \beta$-mercaptoethanol slightly inhibited about $14 \%$ of the enzyme activity while 1 $\mathrm{mM} \beta$-mercaptoethanol did not inhibit enzyme activity. Similarly, EDTA and Urea at both concentrations of 1.0 and $10.0 \mathrm{mM}$ did not inhibit cellulase activity. This is shown in Table 4.

Table 4. Effect of some inhibitors on cellulase activity from Termite soldiers

\begin{tabular}{lll}
\hline \multirow{2}{*}{ Compounds } & \multicolumn{2}{c}{$\%$ Residual Activity } \\
\cline { 2 - 3 } & $1.0 \mathrm{mM}$ & $10.0 \mathrm{mM}$ \\
\hline EDTA & 100 & 100 \\
Urea & 100 & 100 \\
$\beta$-Mercaptoethanol & 100 & 86 \\
\hline
\end{tabular}

Percentage of residual activity is compared with the activity of the enzyme in the absence of the chelating agents.

\section{Discussion}

A greater percentage of cellulotic enzymes have been produced and characterized from fungi, bacteria and several insects including termites. Cellulase is a very important hydrolytic enzyme. Over the years, several authors have purified and reported properties of cellulase from a wide range of termite species including Nasutitermes walkeri (Schultz et al., 1986), Macrotermes mulleri (Rouland et al., 1988), Reticulitermes speratus (Watanabe et al., 1997), Hodotermopsis sjostesti and Nasutitermes takasagoensis (Fujita et al., 2008). Previously, Fagbohunka et al. (2014) only partially purified cellulase from Ametermes eveuncifer and carried out inhibition studies along with other enzymes. In this paper, we report the properties of cellulase from A. eveuncifer following the purification and detailed characterization of the enzyme.

Cellulases have been found to be present in both flagellate-harbouring and flagellate-free termites. Findings by Tokuda and Watanabe (2007) showed that cellulases present in the flagellate-free termites, Nasutitermes takasagoensis and Nasutitermes walkeri were produced by symbiotic bacteria present in the hind gut of these termites, although cellulase activities in the guts of flagellate-free termites were significantly lower than those of flagellate-harbouring termites (Tokuda et al., 2004; 2005). Cellulase characterized from various higher and lower termites have been shown to be similar in a number of properties in some bacteria and fungi (Watanabe et al., 1997). Properties of cellulase from various termites can therefore be compared with those of microorganisms which also play a role in the digestion of cellulose in the gut of termites.

Following the three-step purification of cellulase from A. eveuncifer, a specific activity of $5.04 \mathrm{U} / \mathrm{mg}$ was obtained. It is often difficult to compare activity assays among studies because various factors such as temperature, substrate, detection methods e.t.c. can influence the activity (Willis et al., 2010). It would be more interesting to make a comparison of cellulase activities among different castes of termites within the same species or different species under similar experimental conditions. Unlike the worker termites which collect cellulose to feed the colony, soldier termites defend the colony from attack because they possess specialized morphology for colony defence, but their feeding activity is dependent on other colony members (Fujita et al., 2008). It is therefore expected that the cellulase enzymatic activities and gene expression of the termites will differ greatly from one caste to another and from species to species. 
The cellulase activity was affected by the $\mathrm{pH}$ and temperature of the reaction mixture. It was observed that the optimum condition of enzyme activity by the soldier termites was $\mathrm{pH} 8$ and temperature $50{ }^{\circ} \mathrm{C}$ which are in agreement with that reported by Lima et al. (2005) for Bacillus pumilus strain. The optimum temperature value was the same in comparison to that obtained with the cellulase from the Reticulitermes speratus (Kolbe), a Japanese Subterranean Termite (Watanabe et al., 1997) and very close to that from the digestive tract of the termite Macrotermes mulleri, in which an optimum temperature of $55^{\circ} \mathrm{C}$ was observed (Rouland et al, 1988). A similarly high optimum temperature $\left(55-60^{\circ} \mathrm{C}\right)$ was observed for the cellulase produced by Streptomyces malaysiensis and Streptomyces sp. as reported by Nascimento et al. (2009) and Jaradat et al. (2008). A lower optimum temperature of $40{ }^{\circ} \mathrm{C}$ was reported by El-Sersy et al. (2010) for cellulase from Streptomyces ruber.

Regarding optimum $\mathrm{pH}$ for cellulase in other studies, optimum enzyme activity was found at $\mathrm{pH} 7.0$ in Pseudomonas fluorescence (Bakare et al., 2005) and Bacillus amyoliquefaciens DL3 (Lee et al., 2008). However, lower optimum $\mathrm{pH}$ (5.0) for enzyme activity with broad ranges of $\mathrm{pH}$ stability was observed in Thermomonospora sp. (George et al., 2001), and in Bacillus strain M-9 (Bajaj et al., 2009). An optimum pH of 6.0 was reported for the Japanese Subterranean Termite, Reticulitermes speratus (Watanabe et al.1997). Cellulase was optimally active at alkaline pH in Bacillus sphaericus JS1 (Singh et al., 2004) and Bacillus sp. HSH-910 (Kim et al., 2005).

All the metals inhibited cellulase activity except $\mathrm{Ba}^{2+}$ at $1 \mathrm{mM}$ and $\mathrm{Pb}^{2+}$ at $10 \mathrm{mM}$. The inhibition of the enzyme by the other metals $\left(\mathrm{Na}^{+}, \mathrm{K}^{+}, \mathrm{Mn}^{2+}\right.$ and $\left.\mathrm{Ni}^{2+}\right)$ to various degrees may be a result of interaction of these metal ions with sulfhydryl groups at the enzyme catalytic site (Yin et al., 2010) or induction of changes in the secondary and tertiary structure of the enzyme. Such structural changes have been reported after incubation of protein with metal ions. According to Stokinger (1981), metal ions showing enzyme inhibition are those that have a strong affinity for ligands such as cysteinyl, phosphate and histidyl side chains of protein. The results obtained in this work are in agreement with that from Fagbohunka et al. (2015) who reported that chloride salts of $\mathrm{Hg}^{+}, \mathrm{Mn}^{2+}, \mathrm{Na}^{+}, \mathrm{Co}^{2+}, \mathrm{NH}_{4}^{+}$, $\mathrm{Zn}^{2+}, \mathrm{Ba}^{2+}$ and $\mathrm{Sn}^{2+}$ greatly inhibited cellulase from A. eveuncifer soldiers at $1 \mathrm{mM}$ concentration of the salts. Following the inhibition studies by Fagbohunka et al. (2015), it was recommended that one of the chloride salts of these metals or a combination of at least two can be used for the design of a pesticide for termites such that the organism may not be able to metabolise wood even if it feeds on it. Thus, the organism will be unable to hydrolyze the cellulolytic materials they feed on caused by an inhibition of the metabolic enzymes by chloride salts of the metals. These definitely will result in the death of the organism. Before this study, it had been reported previously that cellulases are inhibited in the presence of heavy metals including $\mathrm{Mn}^{2+}$ (Mawadza et al., 2000).

Further studies can elucidate the co-existence of cellulase produced by the different microorganisms present in the digestive tract of these termites and the properties of these can be compared with cellulases in the different regions of the termite guts (mid and hind gut). The kinetic data and the physical properties of the enzyme can be compared to know if the enzymes are identical or not. From such studies, important inferences can be drawn on how the cellulase system of this species accomplish cellulose digestion.

\section{Conclusion}

Cellulase enzyme was purified from $A$. eveuncifer soldiers and its maximum enzymatic activity was obtained at $50^{\circ} \mathrm{C}$ and $\mathrm{pH}$. The properties of cellulase from the soldier termites are similar to those of the enzyme from other organisms. It is plausible to assume that the enzyme is involved in cellulotic hydrolysis by hydrolyzing the $\beta-1,4$ linkages of cellulose to glucose units. Further inhibition studies of the cellulase system enzymes would reveal the most potent inhibitors and may lead to the development of potential pesticides for termite control.

\section{References}

Bajaj, B. K., Pangotra, H., Wani, A. M., Sharma, P., \& Sharma, A. (2009). Partial purification and characterization of a highly thermostable and $\mathrm{pH}$ stable endoglucanase from a newly isolated Bacillus strain M-9. Indian $J$ Chem Technol., 16, 382-387.

Bakare, M. K., Adewale, I. O., Ajayi, A., \& Shonukan, O. O. (2005). Purification and characterization of cellulase from the wild-type and two improved mutants of Pseudomonas fluorescens. African J Biotechnol., 4, 898904.

Bradford, K. M. (1976). A rapid and sensitive method for the quantitation of microgram quantities of protein utilizing the principle of protein-dye binding. Analytical Biochemistry 72, 248-254.

Breznak, J. A., \& Brune, A. (1994). Role of microorganisms in the digestion of lignocellulose by termites. Annu. Rev. Entomol., 39, 453-487. 
Brune, A., \& Stingl, U. (2005). Prokaryotic symbionts of termite gut flagellates: phylogenetic and metabolic implications of a tripartite symbiosis. In Molecular basis of symbiosis (pp. 39-60). Springer Berlin Heidelberg.

Chakraborty, N., Sarkar, G. M., \& Lahiri, S. C. (2000). Cellulose degrading capabilities of cellulolytic bacteria isolated from the intestinal fluids of the silver cricket. Environmentalist, 20(1), 9-11.

El-Sersy, N. A., Abd-Elnaby, H., Abou-Elela, G. M., Ibrahim, H. A. H., \& Toukhy, N. M. (2010). Optimization, economization and characterization of cellulase produced by marine Streptomyces ruber. African Journal Biotechnology, 9, 6355- 6364.

Fagbohunka, B. S., Edorh, S. E., Adeyanju, M. M., Ezima, E. N., Alabi, M. A., \& Ogunlabi, O. O. (2015). Activities of a Cellulase of the Termite, Ametermes eveuncifer (Silverstri) Soldier: Clue to Termites Salt Intolerance. Journal of Natural Sciences Research, 5(11), 117-123.

Fagbohunka, B. S., Ezima, E. N., Adeyanju, M. M. Alabi, M. A., Oyedele, D. E., \& Adeneye, A. A. (2014) Inhibition Studies of some Key Enzymes of the Termite Ametermes eveuncifer (Silverstri) Workers: Clue to Termites Salt Intolerance. Science Focus, 19(1), 81-87.

Fujita, A., Miura, T., \& Matsumoto, T. (2008) Differences in cellulose digestive systems among castes in two termite lineages. Physiological Entomology, 33(1), 73-82.

George, P. S., Ahmad, A., \& Rao, M. B. (2001) Studies on carboxymethyl cellulase produced by an alkalothermophilic actinomycete. Bioresource Technol., 77, 171-175.

Hogan, M., Veivers, P. C., Slaytor, M., \& Czolij, R. T. (1988). The site of cellulose breakdown in higher termites (Nasutitermes walkeri and Nasutitermes exitiosus). J. Insect Physiol., 34, 891-899.

Inoue, T., Murashima, K., Azuma, J. L., Sugimoto, A., \& Slaytor, M. (1997). Cellulose and xylan utilization in the lower termite Reticulitermes speratus. J. Insect Physiol., 43, 235-242.

Jaradat, Z., Dawagreh, A., Ababneh, Q., \& Saadoun, I. (2008). Influence of culture conditions on cellulase production by Streptomyces sp. (Strain J2). Jordan J. Biol. Sci., 1, 141-146.

Kim, J. Y., Hur, S. H., \& Hong, J. H. (2005). Purification and characterization of an alkaline cellulase from a newly isolated alkalophilic Bacillus sp. HSH-810. Biotechnol Lett., 27, 313-316.

Lee, Y. J., Kim, B. K., Lee, B. H., Jo, K. I., Lee, N. K., Chung, C. H., ... Lee, J. W. (2008). Purification and characterization of cellulase produced by Bacillus amyoliquefaciens DL-3 utilizing rice hull. Bioresource Technol., 99, 378-386.

Lima, A. O., Quecine, M. C., Fungaro, M. H., Andreote, F. D., Maccheroni, W. Jr., Araújo, W. L., ... Azevedo, J. L. (2005). Molecular characterization of a beta-1,4-endoglucanase from an endophytic Bacillus pumilus strain. Appl. Microbiol. Biotechnol., 68, 57- 65.

Lu, J., Deng, T., Li, J., \& Mo, J. (2010). Activities of some lignocelluloses-degrading enzymes in workers of five common termites (Isoptera). Sociobiology, 55(3), 749-762.

Lu, W. J., Wang, H. T., \& Nie, Y. F. (2004). Effect of inoculating flower stalks and vegetable waste with ligno-cellulolytic microorganisms on the composting process. Journal of Environmental Science and Health, Part B, 39(5-6), 871-887.

Mawadza, C., Hatti-Kaul, R., Zvauya, R., \& Mattiason, B. (2000). Purification and characterization of cellulases produced by two Bacillus strains. Journal of Biotechnology, 83(13), 177-187.

Mishra, S. C. (1991). Carbohydrases in the gut of the termite Coptotermes heimi (Wasm.) (Rhinotermitidae), their origin, distribution and evolutionary significance. Ann.Entomol., 9, 41-46.

Mo, J., Yang, T., Song, X., \& Cheng, J. (2004). Cellulase activity in five species of important termites in China. Applied Entomology and Zoology, 39, 635-641.

Mswaka, A. Y., \& Magan, N. (1998). Wood degradation, and cellulase and ligninase production, by Trametes and other wood-inhabiting basidiomycetes from indigenous forests of Zimbabwe. Mycological Study, 102(11), 1399-1404.

Nascimento, R. P., Junior, N. A., Pereira, N. Jr., Bon, E. P., \& Coelho, R. R. (2009). Brewer's spent grain and corn steep liquor as substrates for cellulolytic enzymes production by Streptomyces malaysiensis. Lett. Appl. Microbiol., 48, 529-535. 
Nutt, A., Sild, V., Prtterson, G., \& Johansson, G. (1998). Progress curve as a means for functional classification of cellulases, Europian Journal of Biochemistry, 258, 200.

Rouland, C., Civas, A., Renox, J., \& Petek, F. (1988). Purification and Properties of Cellulases from the termite Macrotermes mulleri (Termitidae, Macrotermitinae) and its symbiotic fungus Termitomyces sp. Comp. Biochem. Physiol., 91B(3), 449-458.

Schultz, J. E., Slaytor, M., Hogan, M., \& O'Brien, R. W. (1986). Components of cellulase from the higher termite Nasutitermes walkeri. Insect Biochem., 16, 929-932.

Singh, J., Batra, N., \& Sobti, R. C. (2004). Purification and characterization of alkaline cellulose produced by a novel isolate, Bacillus sphaericus JS1. J Ind Microbiol Biotechnol, 31, 51-56.

Slaytor, M. (2000). Energy metabolism in the termite and its gut microbiota. In Termites: Evolution, Sociality, Symbioses, Ecology (pp. 307-332). Springer Netherlands.

Slaytor, M. (1992). Cellulose digestion in termites and cockroaches: what role do symbionts play? Comp. Biochem. Physiol. B., 103, 775-784.

Stokinger, H. E. (1981). Industrial Hygiene and Toxicology. In Hygiene and Toxicology (3rd edn, vol. 2A, pp. 1493-2060). John Wiley and Sons, New York.

Tokuda, G., \& Watanabe, H. (2007). Hidden cellulases in termites: revision of an old hypothesis. Biology Letters, $3(3), 336-339$.

Tokuda, G., Lo, N., \& Watanabe, H. (2005). Marked variations in patterns of cellulose activity against crystallinevs. carboxymethyl-cellulose in the digestive systems of diverse, wood-feeding termites. Physiology Entomology, 30, 372-380

Tokuda, G., Lo, N., Watanabe, H., Arakawa, G., Matsumoto, T., \& Noda, H. (2004). Major alteration of the expression site of endogenous cellulases in members of an apical termite lineage. Molecular Ecology, 13, 3219-3228

Vaithanomsat, P., Chuichulcherm, S., \& Apiwatanapiwat, W. (2009). Bioethanol production from enzymatically saccharified sunflower stalks using steam explosion as pretreatment, Proceedings of World Academy of Science, Engineering and Technology, 37, 140-143

Watanabe, H., Nakamura, M., Tokuda, G., Yamaoka, I., Scrivena, A. M., \& Noda, H. (1997). Site of Secretion and Properties of Endogenous Endo-/3-1,4-Glucanase Components from Reticulitermes speratus (Kolbe), a Japanese Subterranean Termite. Insect Biochemistry and Molecular Biology, 27(4), 305-313.

Whistler, R. L., \& Chen, C. C. (1991). Hemicelluloses. In Wood structure and composition, (eds. M. Lewin and I. S. Goldstein) pp. 287-320. International Fiber Science and Technology Series, Vol. II. Marcel Decker, Inc., New York.

Willis, J. D., Oppert, C., \& Jurat-Fuentes, J. L. (2010). Methods for discovery and characterization of cellulolytic enzymes from insects. Insect Science, 17(3), 184-198.

Yin, L. J., Lin, H. H., \& Xiao, Z. R. (2010). Purification and Characterization of a cellulase from Bacillus subtilis YJ1. Journal of Marine Science and Technology, 18(3), 466-471

Zhang, Y. H. P, Himmel, M. E., \& Mielenz, J. R. (2006). Outlook for cellulase improvement: screening and selection strategies. Biotechnology Advances, 24, 452-481.

\section{Copyrights}

Copyright for this article is retained by the author(s), with first publication rights granted to the journal.

This is an open-access article distributed under the terms and conditions of the Creative Commons Attribution license (http://creativecommons.org/licenses/by/4.0/). 